\title{
Evaluation of marking efficiency of different alizarin red $S$ concentrations on body fish structures in Oreochromis niloticus (Perciformes: Cichlidae) juveniles
}

\author{
Ana L. Ibáñez, Antonio Rodríguez-Canto, Jasmín Cortés-Martínez \& José L. García-Calderón \\ Universidad Autónoma Metropolitana-Iztapalapa, Departamento de Hidrobiología, Av. San Rafael Atlixco 186, Col. \\ Vicentina. México, D.F. 09340, México; ana@xanum.uam.mx, roca@xanum.uam.mx, hada_30@hotmail.com, \\ jlge@xanum.uam.mx
}

Received 13-II-2012. Corrected 09-VIII-2012. Accepted 13-IX-2012.

\begin{abstract}
The use of alizarin red S (ARS) marked tilapias could provide valuable fisheries management information to evaluate fish stocking events and may facilitate aquaculture management practices. As a new technique in fishes, the aim of this study was to compare and evaluate the chemical marks produced in tilapia juveniles by ARS through two treatments: 1) 12 hours of immersion and 2) immersion after osmotic induction. This was analyzed at three concentrations: 50,75 and $100 \mathrm{mg} / 1$, and in three structures: otoliths, fish scales and caudal fin rays of Oreochromis niloticus juveniles. After three culture months $80 \%$ of specimens were analyzed and significant differences $(\mathrm{p}<0.05)$ in mark intensity were detected between treatments for otoliths and fin rays, but not for fish scales. Significant differences between concentrations were found for the $12 \mathrm{~h}$ immersion treatment, while no significant differences were detected with osmotic induction. Our results showed that marks appeared at all concentrations, and none of the concentrations produced weak marks. Osmotic induction had a greater mortality than the $12 \mathrm{~h}$ immersion procedure. After eight culture months the rest of the specimens were analyzed and the mark permanence was observed in all cases. According to the present results we recommend the marking process of $12 \mathrm{~h}$ immersion treatment at 100mg/L concentration. Rev. Biol. Trop. 61 (1): 193-201. Epub 2013 March 01.
\end{abstract}

Key words: dye, tilapia, fish stocking, chemical mark, stock enhancement, alizarin red.

According to FAO (2009), worldwide percapita aquaculture fish consumption has rapidly increased between 1970 and 2006, from 0.7 to $7.8 \mathrm{~kg}$ (with an annual increase rate of $6.9 \%$ ); tilapia culture has been gradually expanding since 1970 and occupies the second place in worldwide aquaculture just after shrimp. Hatchery-bred fish (fingerling production) has been developed to supplement and support the rapidly depleting stocks of freshwater environments (Brown \& Day 2002). The ability to discriminate between wild and hatchery-produced fish fingerlings is vital to evaluate the efficiency and sustainability of stock enhancement. A variety of methods for identification of hatcheryproduced fish have been developed including tagging, chemical marking, and genetic analysis (Nielsen 1992). For age determination purposes, the chemical (e.g. ARS) marking of otoliths has provided a good validation method (Bell 2001). The most reliable validation comes from comparing the increment in otolith size in fish of known ages. Chemical tagging by bath immersion is an efficient method in fish, since individual handling is not required and it is possible to mark numerous specimens in the same batch at low costs (Mauk 2008). These methods are used to produce marks in otoliths or other calcified structures by immersion in fluorescent colorants, such as oxytetracycline (OTC), calceine or ARS during a predetermined exposure period (6-12h). 
Different chemicals have been successfully used for fish and specifically, several for cichlids. Klesius et al. (2006), used calceine to discriminate between a vaccinated population of tilapia (Oreochromis niloticus L.) and other not treated populations. They found a detectable fluorescent band following a fourhour-bath in 500mg/l. Egger (2004) used tetracycline to validate the pattern of increment in the otoliths of Tropheus moorii Boulenger (1898), a native cichlid of Lake Tanganyika, where marking involved individually injecting each fish with $10 \mathrm{~mm}(4.4 \mathrm{mg} / 1)$ of tetracycline solution. Likewise, Barker \& McKaye (2004), marked juveniles of the cichlid Amphilophus, with OTC concentrations of 200, 400 and $600 \mathrm{mg} / \mathrm{l}$ in four, eight or $16 \mathrm{~h}$ treatments; as a result they defined an optimal concentration of $600 \mathrm{mg} / \mathrm{l}$ after an eight hours bath. Besides, Mauk (2008), worked with OTC to assess the effectiveness of marking techniques in otoliths of Palmetto Bass (striped bass hybrid) that live in hard waters, using concentrations of 500 and $700 \mathrm{mg} / \mathrm{l}$ during a six hour fixed period. Marks were detectable in 63 and $74 \%$ of individuals, respectively.

Immersion in a dye, combined with osmotic induction, is a technique consisting of a brief salt bath prior to immersion in a fluorescent dye. This procedure dramatically reduces color absorption time, in comparison to conventional methods of marking. Simplicity and speed of osmotic induction make this method especially suitable for marking fish on a large scale where cost and logistics largely determine the utility of marking methods (Mohler 2003). Crook et al. (2007 \& 2009) also evaluated osmotic methods for golden perch Macquaria ambigua using ARS. They found that the osmotic induction-marked fish possessed more intense marks and that these marks remained visible nine months after treatment. Mark production using ARS it is consider as nontoxic for several species (Lucas et al. 2008, Simon et al. 2009) and human consumption; also is acceptable to the public for commercial use (Rothlisberg \& Preston 1992).
In Mexico, the federal government supports 40 fish farms that produce, on average, 111 million fry per year, $48 \%$ of which are tilapia. Although culture-based fisheries in Mexico are almost one century old, there is very little information available as to their influence on fish production (Ibáñez 2004, Ibáñez et al. 2011). The release of ARS-marked tilapias could provide valuable fisheries management information and assist in evaluating release strategies which optimize survival, and migration patterns that affect productivity and interbreeding with wild fish.

The aim of this study was to compare and evaluate the chemical mark produced by ARS through two treatments: 1) $12 \mathrm{~h}$ of immersion and 2) immersion after osmotic induction. This was analyzed using three different concentrations: 50,75 and $100 \mathrm{mg} / 1$; and evaluating their effect in three body fish structures: otoliths, fish scales and rays from the caudal fin.

\section{MATERIAL AND METHODS}

Fish transportation and acclimation: Juveniles of the Stirling strain of Oreochromis niloticus L. were obtained from a fish farm at Zacatepec, in the State of Morelos, Central South Mexico. They were transported to the Fisheries laboratory at the Metropolitan University in Mexico City, in plastic bags filled with fresh water and oxygen. Fish were acclimated for seven weeks in an aerated 200-1 tank with a Fluval filter model 305 (volume of $710 \mathrm{l} / \mathrm{h}$ ) and fed to satiation twice a day each day with tilapia pellets (32\% of protein). They were then transferred to a recirculating system with a matured biofilter and 14 plastic aquariums, each of a 12-1 capacity. Temperature was controlled with a thermostat of $1000 \mathrm{~W}$ located in the biofilter container. Air was provided by a blower net system. Seven individuals were housed in each aquarium for one week prior to treatment. A total of 112 fish were analyzed; 56 per treatment: two replicates of seven fish (14 specimens by each of three chemical concentrations), and 14 specimens were used for control analysis. The total mean length of these 
juveniles was $6.7 \pm 0.63 \mathrm{~cm}$ (range, $5.0-7.8 \mathrm{~cm}$ ) while total mean weight was $3.8 \pm 1.62 \mathrm{~g}$ (range, $1.7-6.9 \mathrm{~g}$ ) at the beginning of the experiment when fish was two months old. To avoid infections, methyl blue and salt were occasionally added to the reservoir of the recirculation system. Water temperature $\left({ }^{\circ} \mathrm{C}\right)$, salinity (PSU), total dissolved solids $(\mathrm{g} / \mathrm{l})$, oxygen $(\mathrm{mg} / \mathrm{l})$ and $\mathrm{pH}$, were daily measured using an YSI multimeter model MSP 556.

Experimental design: Two experimental treatments were evaluated. In treatment 1 , fish were removed from aquaria and immersed in 10-1 solutions of 50, 75 and $100 \mathrm{mg} / \mathrm{l}$ ARS (Baker Analyzed ${ }^{\circledR R}$ eagent) for a period of $12 \mathrm{~h}$. Treatment 2 consisted of a previous osmotic induction, following Crook et al. (2007) protocol; for this, fish were immersed in a $5 \%$ sea-salt solution for five minutes, followed by a five seconds rinse in aquarium water, and then, a 10 minute immersion in the ARS solution of $10-1$ with the respective 50,75 and $100 \mathrm{mg} / 1$ concentration. The salt was from "Salinas del Márquez" brand obtained from evaporation of the Pacific coast water of Salina Cruz, Oaxaca, México. The salt solution was prepared by dissolving $500 \mathrm{~g}$ of commercial sea salt in a 10-1 of fresh water. As unmarked controls, an additional group of seven fish was immersed in a $5 \%$ salt solution for $5 \mathrm{~min}$ without immersion in ARS solution. Aerated 10-1 buckets were used in all treatments; each replicate was manipulated in a different bucket.

After the marking process, all fish from different treatments and replicates were maintained and fed to satiation for three months in different aquaria in a recirculation system. Afterwards, from October 2009, five fish (from the seven) from each treatment were sacrificed and examined; all the results analysis showed here correspond to these five specimens. Additionally, to assess the permanence of the mark the two remaining fish were examined five months later to assess the longevity of the mark. This accounted for a commercial size that is normally reached after approximately eight months following stocking. Fish were euthanized by adding cold water to produce a gentle death. Afterwards, total length and total weight were measured, and scales, otoliths and caudal fins were obtained.

\section{Structure preparation and examination:}

Scales were cleaned and placed between two glass slides for observation. Caudal fin rays were placed on an excavated slide glass. Otoliths were sanded in the sagittal plane and fixed on an excavated glass. Structures were examined using an epifluorescence microscope (Zeiss Axio Start) fitted with a TXR filter set. The TXR filter set has an excitation filter BP560/40, beamsplitter FT585 and with emission BP630/75. Structures were examined in a darkened room to reduce external light effect, and digital photographs were taken with four-x magnification using a Canon camera.

To assign a mark intensity value based on an ordinal scoring system, the following five classifications were established: no mark, weak mark, moderate mark, intense mark and very bright mark (modified from Crook et al. 2007). In order to determine significant differences between the ARS concentrations used, Kruskal-Wallis tests were used; furthermore, a Mann-Whitney U-test was used to determine significant differences in mark intensity between the ARS treatment groups and between concentration replicates. Differences were considered significant at $\mathrm{p}<0.05$.

Fish were treated in compliance with the regulations and protocols of our University (Lineamientos para la conducción ética de la investigación, la docencia y la difusión en la División de Ciencias Biológicas y de la Salud de la Universidad Autónoma Metropolitana (http://cbs.izt.uam.mx/informacion/consejo_ divisional/index.htm).

\section{RESULTS}

The results shown here are from the specimens maintained for three months, while in the mark permanence subtitle are the results from fish eight months old. 
Mortality: Mortalities reached 12.24\% in the $12 \mathrm{~h}$ ARS immersion treatment (Treatment 1 ), and $22.4 \%$ in the osmotic inductionARS immersion treatment (Treatment 2). In treatment 1 , fish remained at the bottom of the buckets during chemical exposure and no excessive movements were observed. Mortalities for this treatment group occurred during the subsequent growth period, but no mortality was observed during chemical exposure itself. For treatment 2, the fins of fish immersed in the $5 \%$ salt solution turned to a noticeable white color and many individuals lost equilibrium and floated to the surface; most of these were stressed. Highest mortalities in this treatment occurred during the first week after this osmotic treatment. The stress behavior occurred only in the osmotic treatment, suggesting that the cause was the salt rather than the ARS.

General mark results for both treatments: Moderate and intense marks were the most frequent results in both treatments $(38.8$ and $36.1 \%$, respectively) for the whole period. Caudal fins depicted the highest mark intensity followed by those in the otoliths. The control treatment for the 12-hour immersion showed no marks, whilst the osmotic induction control exhibited autofluorescence in all three structures (Figs. 1,2). Mark intensity was not significantly different between duplicates for the two
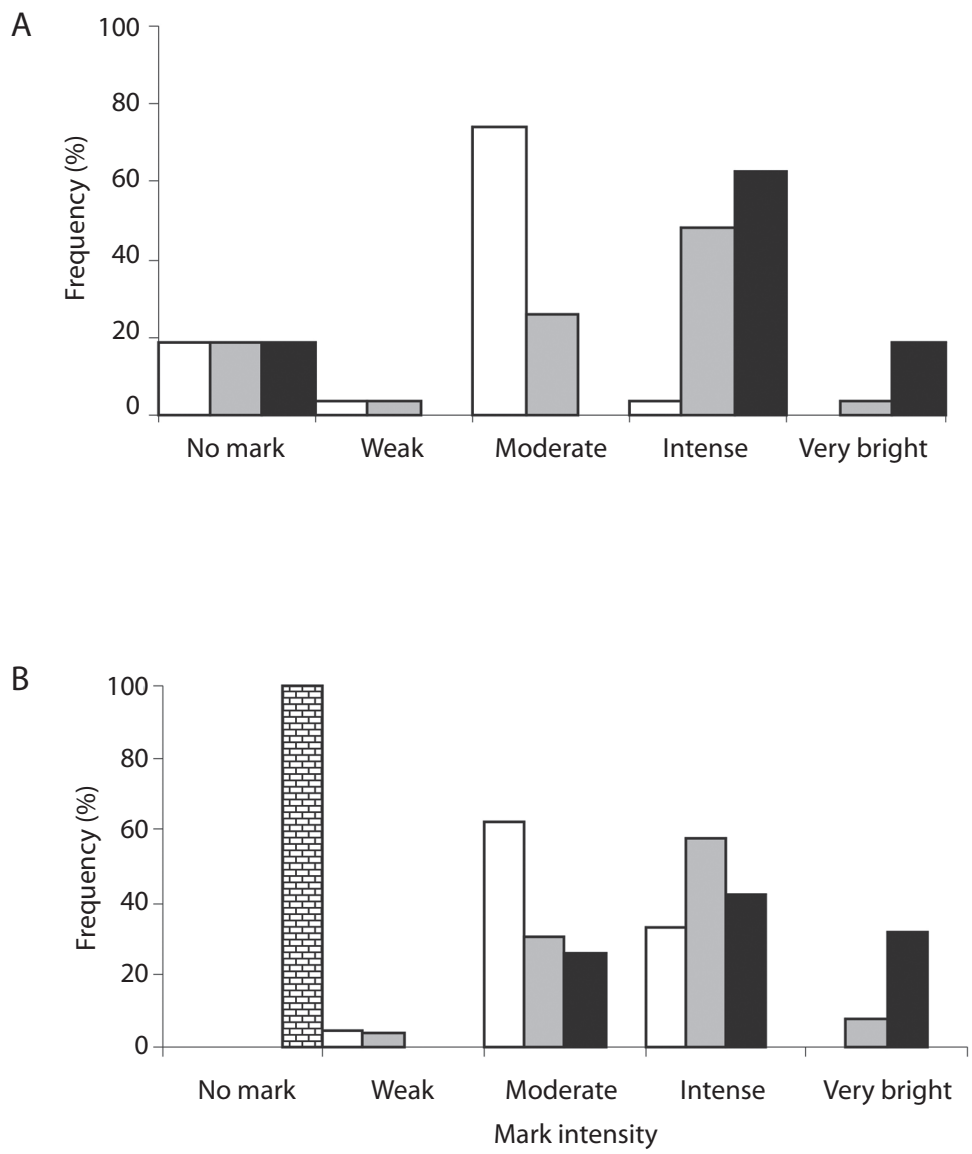

Fig. 1. Frequency (\%) in mark intensity values for the $12 \mathrm{~h}$ immersion treatment (Treatment 1). a) By structure: white bars $=$ fish scales; grey bars $=$ otoliths and black bars $=$ caudal fin. b) By concentration: white bars $=50 \mathrm{mg} / 1$; grey bars $=75 \mathrm{mg} / 1$ and black bars $=100 \mathrm{mg} / 1$, grid bar=control. 

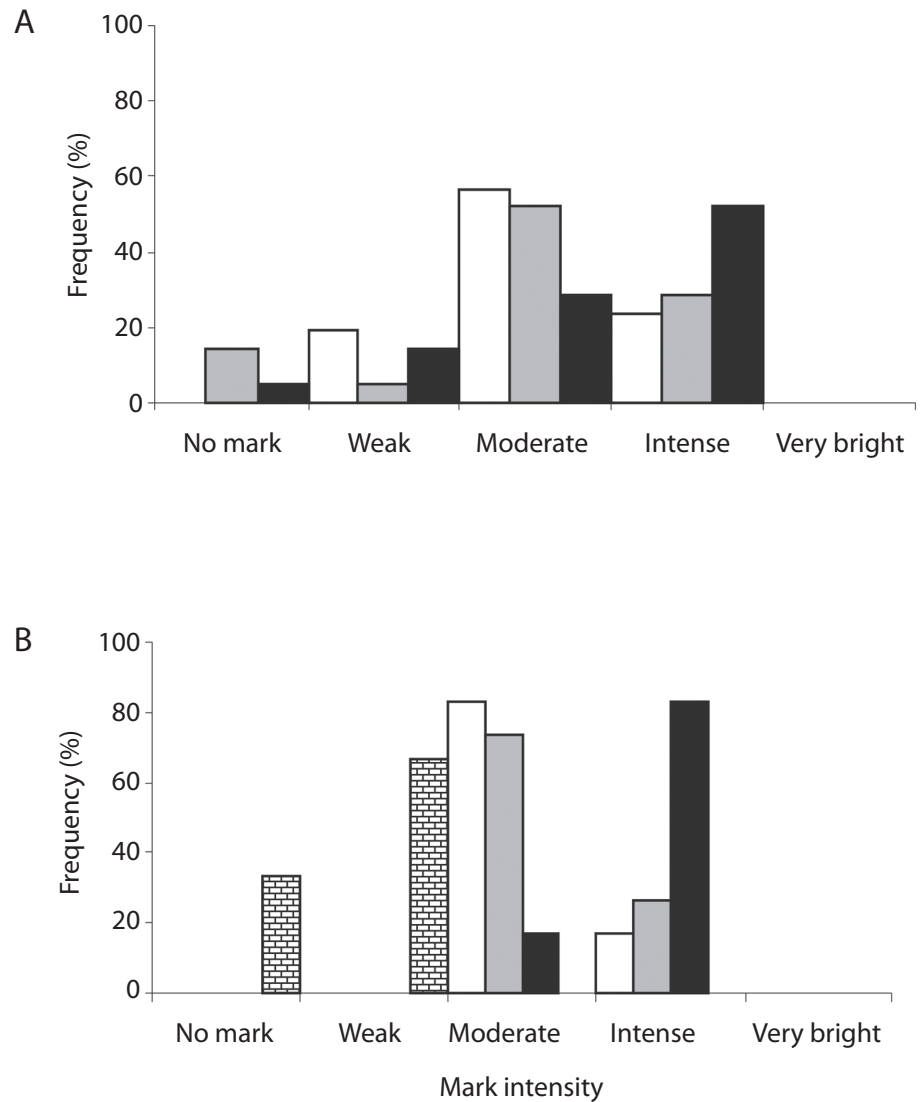

Fig. 2. Frequency (\%) in mark intensity values for the osmotic induction treatment (Treatment 2). A) By structure: white bars=fish scales; grey bars $=$ otoliths and black bars $=$ caudal fin ray. B) By concentration: white bars=50 $\mathrm{mg} / \mathrm{l}$; grey bars $=75 \mathrm{mg} / 1$ and black bars $=100 \mathrm{mg} / 1$, grid bars $=$ control.

treatments (Treatment 1: $\mathrm{p}=0.509$; Treatment 2: $\mathrm{p}=0.964)$. There were significant differences between treatments for caudal fin $(p=0.001)$ and otoliths $(\mathrm{p}=0.019)$, but not for scales $(p=0.302)$. Significant differences were found for ARS concentrations in scales $(p=0.001)$.

Treatment 1: Mark intensity in the $12 \mathrm{~h}$ immersion treatment of otoliths showed wide variability, while most scales had moderate intensity marks $(74.1 \%)$. Likewise, most caudal fin marks were intense $(63.0 \%)$. It is important to mention that the $20 \%$ frequency in the no mark results showed in figure 1a, applies to control specimens. In the $50 \mathrm{mg} / \mathrm{L}$ batch, $62.5 \%$ of the marks were moderate while very bright marks were not observed. Most of the $75 \mathrm{mg} / \mathrm{l}$ concentration batch showed either intense $(57.7 \%)$ or moderate marks $(30.8 \%)$; while intense $(42.1 \%)$ and very bright marks $(31.6 \%)$ increased in the $100 \mathrm{mg} / \mathrm{l}$ group. At this higher concentration, no weak marks were formed (Fig. 1b). This treatment showed differences between 50 and $75 \mathrm{mg} / 1$ and also between 50 and $100 \mathrm{mg} / 1$ for otoliths $(p=0.003$ and $\mathrm{p}=0.001$, respectively). Also, differences in ARS concentrations, for caudal rays in the 12-hour treatment, were notable between 75 and $100 \mathrm{mg} / 1$, and 50 and $100 \mathrm{mg} / 1(\mathrm{p}<0.000$ and $\mathrm{p}=0.001$, respectively). 
Treatment 2: The osmotic induction treatment did not produce very bright marks in any case (Figs. 2, 3); most of the marks were moderate or intense. This treatment did not produce differences among concentrations in otoliths and caudal fin rays $(\mathrm{p}=0.09)$. Approximately, $50 \%$ of otoliths and scales from osmotic immersion showed moderate marks (28.6\%), followed by intense marks (23.8\%), while $52.3 \%$ of caudal fin depicted intense and $28.6 \%$ moderate marks (Fig. 2a). At 50 and $75 \mathrm{mg} / 1$ most marks were moderate with $83.3 \%$ and $73.3 \%$, respectively. On the other hand, at $100 \mathrm{mg} / 1,83.3 \%$ of the marks were intense.
Environmental parameters: During the eight-month culture period, water temperature ranged from 15.9 to $27.0^{\circ} \mathrm{C}(21.0 \pm 2.3), \mathrm{pH}$ from 8.9-9.3 (9.3 \pm 0.3$)$, oxygen ranged from 4.7 to $6.4 \mathrm{mg} / \mathrm{l}(5.2 \pm 1.0)$, salinity from 5.0 to 8.2 PSU (6.5 \pm 1.0$)$ and total dissolved solids from 3.4 to $8.6 \mathrm{~g} / 1(7.4 \pm 1.3)$. Temperature and oxygen, in particular, fluctuated widely during the day. Most of these variations were due to the time of day that samples were taken. Additionally, temperature variation was also due to a harsh winter, which demanded artificial heating to better represent conditions the fish would have experienced in the wild, for the
Control
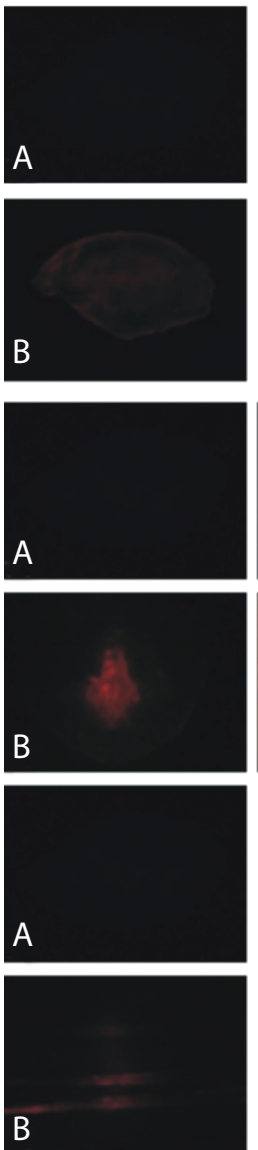

$100 \mathrm{mg} / \mathrm{L}$
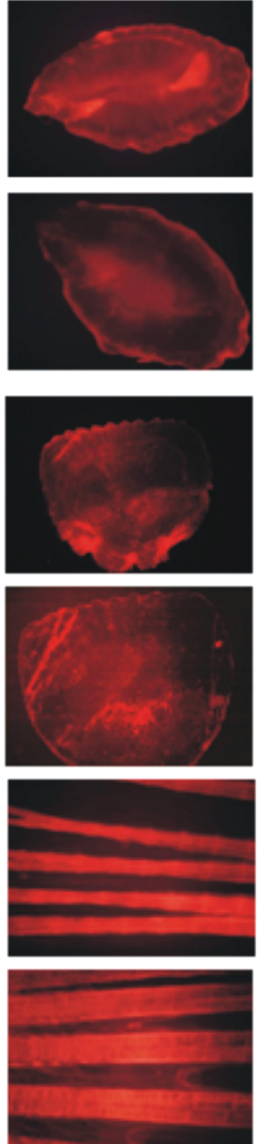

$75 \mathrm{mg} / \mathrm{L}$
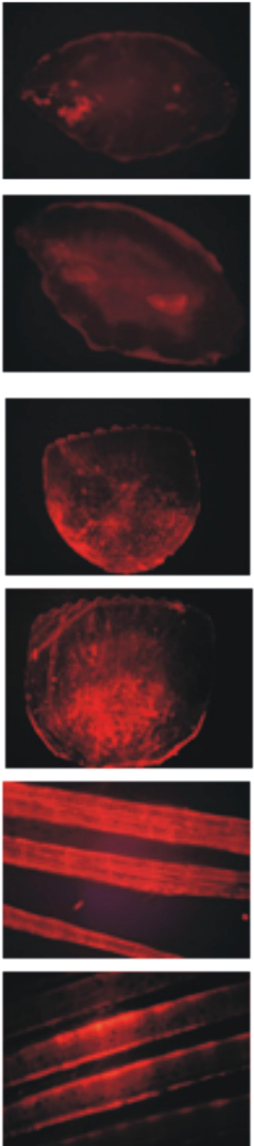

$50 \mathrm{mg} / \mathrm{L}$
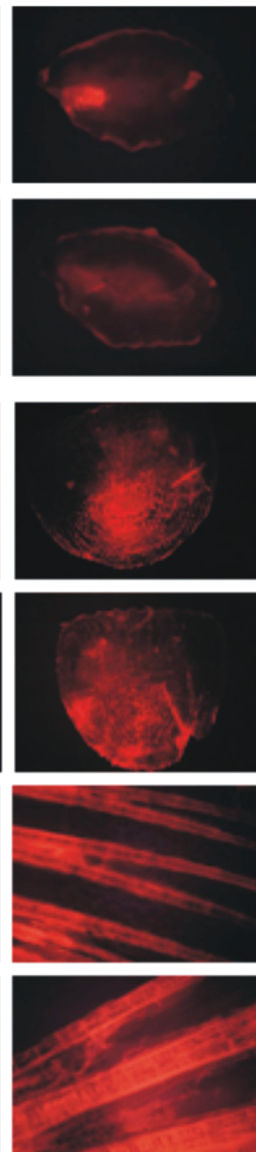

Fig. 3. Photographs of control (left) and marked tilapia, three months after chemical exposure. a) Results of the $12 \mathrm{~h}$ immersion treatment (Treatment 1) and b) Results of the osmotic induction treatment (Treatment 2). The three ARS solutions of 50,75 and $100 \mathrm{mg} / 1$ appear in the three columns to the right, in the respective order. The three structures from top to bottom are otoliths, scales and caudal fin rays. 
eight months period. After three months, fish total length range was between $5.3-9.2 \mathrm{~cm}$, with a mean of $7.3 \pm 0.85$.

Mark permanence: As it was mentioned, two remaining fish from different treatments and dye concentrations were examined at eight months age. The three structures (otoliths, fins and scales) of the two treatments were checked for marks under a UV light microscope. In all cases $(100 \%)$, marks were visible, nevertheless it was not evaluated the mark intensity value. Although the small number of specimens investigated does not permit statistical analysis by treatment and concentrations. The visibility of the marks after eight months clearly indicates that the chosen methods allow for recognition of released individuals.

In summary, mark intensity did not differ between replicates. There were differences between treatments in the results obtained for caudal fins and otoliths, but not for scales. ARS concentrations only produced different intensities in treatment 1. Osmotic induction treatment did not result in very bright marks. Different ARS concentrations produced marks going from weak to intense with the exception of the $100 \mathrm{mg} / 1$, which did not produce weak marks.

\section{DISCUSSION}

In this study, mortality resulted greater than in other similar studies (Leips et al. 2001, Bashey 2004, Crook et al. 2007, Crook et al. 2009). Size of fish could be an explanation of these results since, in those studies, fish were smaller and we observed that small fish were less vulnerable to the osmotic immersion shock. As a consequence of exposing the tilapia to high salinity water, the fish cells loose a certain amount of water. When the tilapias return to the ARS solution, the consequential osmotic differences resulted in the rapid uptake of dye, as water was replaced via osmosis through the skin and gills (Mohler 2003); this generated an efficient utilization of dye independently of the ARS concentrations, and the reduction in immersion time (Mohler 2003, Negus \& Tureson 2004) and high-quality marks (Crook et al. 2007). Nevertheless, osmotic induction marking with ARS produced more mortality than the 12-hour immersion treatment; we do not discard that lower salt immersion times might produce less mortality. According to Crook et al. (2007) increasing the immersion time beyond $3.5 \mathrm{~min}$ may not necessarily improve the mark quality in golden perch fingerlings. Although osmotic induction marking with ARS requires supplementary testing, we believe that has significant potential since is less time consuming, however, the exploration of longer or shorter periods of immersion in both the salt and ARS solutions that could enhance the intensity of the mark should be experimented.

This experiment has demonstrated the promising use of ARS to mark tilapia by immersion and by osmotic induction techniques; nevertheless, several issues must be addressed, e.i. according to Simon et al. (2009) the growth and mortality of European glass eel Anguilla anguilla 192 days after marking with oxytetracycline and alizarin red S were not significantly different between the two treatments and not different to the unmarked $A$. anguilla. The study provided evidence that both marking methods (OTC and ARS) fulfill the capturerecapture assumption of no effect on growth and survival within the glass-eel $A$. anguilla stage. Therefore, it must be studied the species specific effects of the marking techniques on growth and mortality rates.

The affinity of the ARS to calcium could explain that the caudal fin ray was the structure that showed the best mark intensities, followed by otoliths and fish scales, since fin rays and otoliths are constructed by calcareous elements (Estrada 1977), while fish scales consist of an outer, initially non-calcified matrix (Wallin 1957). The present results shows that fin rays of tilapia is a good structure for tagging revision, since fish mark could be evaluated without fish sacrifice.

Bashey (2004) and Crook et al. (2009) also reported the presence of weak marks in non-exposed controls using osmotic immersion 
treatments. Even so, auto-fluorescence does not present a problem because it is easily distinguished from chemical marks. Natural fluorescence is due in large part to substances like flavins, porphyrins, lipofuscin and (in plants) chlorophyll. Lipofuscin is the breakdown product of old red blood cells with fluorescent red under green excitation. Elastin and collagen also could produce autofluorescence. Elastin contains several fluorophores, one of which is a crosslinking tricarboxylic amino acid with a pyridinium ring (Deyl et al. 1980). This is a similar fluorophore to the one found in collagen. The elastine in presence of a saline solution, even for $10 \mathrm{~min}$ followed by a $5 \mathrm{~min}$ wash, shifts the usual green autofluorescence emission of elastin into a red emission (Neumann \& Detlef 2002). The mentioned substances could have produced the autofluorescence in the control specimens of shock osmotic treatment; nevertheless, to be certain it will be necessary to design a particular study to explore this aim.

Mark permanence is decisive in dye election. In this study ARS showed eight months permanence. According to Simon et al. (2009) fish marks with ARS and oxytetracycline were clearly visible after a period of two years in specimens of Anguilla anguilla. The visibility of the marks eight months after marking definitely indicates that the chosen methods allocate for recognition of released individuals. ARS-marked larvae and juveniles of other fish species as Macquaria ambigua and Thymallus thymallus has been retained from months to years (Beckman \& Schulz 1996, Crook et al. 2007).

The concentrations of ARS solutions had an effect in the mark intensity, higher concentrations produce better marks than lower concentrations. The selection of diverse pigment concentrations must be made taking into consideration the importance of mark quality in opposition to the expenses and logistics of the marking method. These decisions will be related to the particular aims and restrictions of the study or marking agenda.

The present results indicate that ARS facilitate easy and rapid mass-marking of big number of tilapia and as well, could be used for fisheries assessment. The chemical marks offer suitable modes of induction, long-term marks over time. Fishes fit in ARS into calcifying tissues while growing within some hours and as a result, the mark can be recognized under UV light as a fluorescent mark which can facilitate the growth rate and relative age at recapture of the fish.

In conclusion, both treatments and all concentrations produced useful marks, but the $100 \mathrm{mg} /$ treatment did not produce weak marks. Control in the 12-hour immersion did not mark while auto-fluorescence appeared in the osmotic treatment control. The osmotic treatment resulted in greater mortality rates than the $12 \mathrm{~h}$ immersion; thus, a concentration of $100 \mathrm{mg} / 1$ combined with a $12 \mathrm{~h}$ immersion in ARS can be recommended for hatchery produced $O$. niloticus in this size range.

\section{ACKNOWLEDGMENTS}

We thank the valuable help in the English adaptation to Anselmo Galindo Molina and to three anonymous referees who really improved the first version of the manuscript. Financial support was obtained from the Universidad Autónoma Metropolitana Iztapalapa.

\section{RESUMEN}

El uso de alizarina roja S (ARS) para marcar tilapias podría proporcionar información valiosa para el manejo de su pesquería. Para evaluar pesquerías acuaculturales manejadas con siembras o repoblamientos de peces se comparó y evaluó la marca producida por la alizarina roja S, empleando dos tratamientos: 1) Inmersión en ARS durante 12h; e 2) Inmersión en ARS después de un choque osmótico. El análisis se realizó a tres concentraciones: 50,75 y 100mg/1 y en tres estructuras: otolitos, escamas y radios de la aleta caudal de Oreochromis niloticus. Ochenta por ciento de los ejemplares fueron cultivados durante tres meses y analizados posteriormente. Los resultados mostraron diferencias entre las concentraciones de la marca para el tratamiento de $12 \mathrm{~h}$ de inmersión mientras que no hubo diferencias entre las concentraciones para el tratamiento con inducción osmótica. Se encontraron diferencias en la intensidad de la marca entre los tratamientos para otolitos y radios de las aletas pero para las escamas no hubo diferencias significativas. Todas las concentraciones produjeron marcas 
(desde débiles a intensas), sin embargo la concentración de $100 \mathrm{mg} / 1$ no produjo marcas débiles. El tratamiento por inducción osmótica presentó mayores niveles de mortalidad. Después de ocho meses de cultivo el resto de los ejemplares fueron analizados y se observó la permanencia de las marcas en todos los casos. En vista de lo anterior, para los propósitos de marcaje se recomienda el uso del tratamiento de inmersión por $12 \mathrm{~h}$ y una concentración de $100 \mathrm{mg} / 1$.

Palabras clave: pigmento, tilapia, siembra de peces, marcaje químico, mejoramiento pesquero.

\section{REFERENCES}

Barker, M.J. \& R.K. McKaye. 2004. Immersion marking of juvenile midas Cichlids with Oxytetracycline. N. Am. J. Fish. Manage. 24: 262-269.

Bashey, F. 2004. A comparison of the suitability of alizarin red $\mathrm{S}$ and calcein for inducing a nonlethally detectable mark in juvenile guppies. T. Am. Fish. Soc. 133: 1516-1523.

Beckman, D.W. \& R.G. Schulz. 1996. A simple method for marking fish otoliths with alizarin compounds. T. Am. Fish. Soc. 125: 146-149.

Bell, M.A. 2001. Fish do not lie about their age...but they might lose count. Trend. Ecol. Evol. 6: 599-600.

Brown, C. \& R.L. Day. 2002. The future of stock enhancements: lessons for hatchery practice from conservation biology. Fish \& Fish. 3: 79-94.

Crook, D.A., D. O’Mahony, B.M. Gillanders, A.R. Munro \& A.C. Sanger. 2007. Production of external fluorescent marks on Golden Perch fingerlings through osmotic induction marking with Alizarin Red S. N. Am. J. Fish. Manage. 27: 670-675.

Crook, D.A., D. O’Mahony, A.C. Sanger, M. Munro \& B. Gillanders. 2009. Development and evaluation of methods for osmotic induction marking of Golden Perch Macquaria ambigua with Calcein and Alizarin Red S. N. Am. J. Fish. Manage. 29: 279-287.

Deyl, Z., K. Macek, M. Adam \& O. Vancikova. 1980. Studies on the chemical nature of elastin fluorescence. Biochim. Biophys. Acta 625: 248-254.

Egger, B. 2004. Validation of the periodicity of increment formation in the otoliths of a cichlid fish from Lake Tanganyika, East Africa. J. Fish Biol. 64: 1272-1284.

Estrada, C.G. 1977. La alizarina en el estudio y clasificación de las escamas su utilidad en el estudio del sistema esquelético de peces, anfibios, y aves. Actualidades Biológicas (Colombia) 6: 80-84.

FAO. 2009. El estado mundial de la pesca y la acuicultura 2008. FAO, Roma, Italia.
Ibáñez, A.L. 2004. Impact of the timing of stocking on growth and allometric index in aquaculture based fisheries. Fish. Manage. Ecol. 11: 81-87.

Ibáñez, A.L., H. Espinosa-Pérez \& J.L. García-Calderón. 2011. Datos recientes de la distribución de siembras de especies exóticas como base de la producción pesquera en aguas interiores mexicanas. Rev. Mex. Biodiv. 82: 904-914.

Klesius, H.P., J.J. Evans, C.A. Shoemaker \& D.J. Pasnik. 2006. A vaccination and challenge model using calcein marked fish. Fish \& Shellf. Immun. 20: 20-28.

Leips, J., C.T. Baril, F.H. Rodd, D.N. Reznick, F. Bashey, G.J. Visser \& J. Travis. 2001. The suitability of calcein to mark poeciliid fish and a new method of detection. T. Am. Fish. Soc. 130: 501-507.

Lucas, T., P.J. Palmer, S. Wang, R. Scoones \& E. O'Brien. 2008. Marking the shell of the saucer arking the shell of the saucer scallop Amusium balloti for sea ranching using oxytetracycline, calcein and alizarin red s. J. Shellfish Res. 27: 1183-1188.

Mauk, R. 2008. Efficacy of Oxytetracycline Marking of Fingerling Palmeto Bass in Hard Water. N. Am. J. Fish. Manage. 28: 258-262.

Mohler, J.W. 2003. Producing Fluorescent Marks on Atlantic Salmon Fin Rays and Scales with Calcein via Osmotic Induction. N. Am. J. Fish. Manage. 23: 1108-1113.

Negus, M.T. \& F.T. Tureson. 2004. Retention and nonlethal external detection of calcein marks in rainbow trout and chinnok salmon. N. Am. J. Fish. Manage. 24: 741-747.

Neumann, M. \& G. Detlef. 2002. Simple Method for Reduction of Autofluorescence in Fluorescence Microscopy. J. Histoch. Cytoch. 50: 437-439.

Nielsen, L.A. 1992. Methods of marking fish and shellfish. American Fisheries Society, Bethesda, Maryland. Special publication 23.

Rothlisberg, P.C. \& N.P. Preston. 1992. Technical aspects of stocking: Batch marking and stock assessment. Recruitment Processes. Australian Society for Fish Biology Workshop. Australian Government Printing Service.

Simon, J., H. Dorner \& C. Richter. 2009. Growth and mortality of European glass eel Anguilla anguilla marked with oxytetracycline and alizarin red. J. Fish Biol. 74: 289-295.

Wallin, O. 1957. On the growth structure and developmental physiology of the scales of fishes. Rep. Inst. Fresh. Res. 38: 385-447. 
